\title{
Analysis of the Influence of Senses, Interior Design, Signage, Facilities, Atmospherics, Staff, Other Visitor's Behavior, The Visitor Himself / Herself on Customer Loyalty through Emotions and Satisfaction of Watsons customers in Surabaya
}

\author{
Chandra Moudy Renata ${ }^{\mathrm{a} *}$, Ronald $^{\mathrm{b}}$, Amelia $^{\mathrm{c}}$ \\ ${ }^{a}$ moudy.renata@gmail.com \\ ${ }^{a}$ Barchelor of Management Student at Pelita Harapan University, Surabaya 60234, Indonesia \\ ${ }^{b, c}$ The Lecturer of Barchelor of Management at Pelita Harapan University, Surabaya 60234, Indonesia
}

\begin{abstract}
The retail industry plays an important role in the business world. In the era of globalization, there will be many changes that will continue to occur. In 2017, the retail industry in Indonesia experienced complaints and tended to decline. One company that has successfully adapted and adjusted its strategy to the circumstances that have occurred is PT. Duta Intidaya Tbk. (DAYA) the manager of the Watsons Indonesia network. Watsons is a leading health and beauty product retailer in Asia which operates 7500 retail stores and 1500 pharmaceutical retail stores in the Asian and European markets, including Indonesia. This study aims to analyze how the influence of Senses, Interior Design, Signage, Facilities, Atmospherics, Staff, Other Visitor's Behavior, and The Visitor Himself / Herself on Customer Loyalty through Emotions. And this study hopes to provide benefits in increasing knowledge in the field of management, especially how much influence Emotions has in increasing Customer Loyalty which will then increase sales from Watsons. Causal research and quantitative methods will be used in this study by processing data in the AMOS version 22.0 application. Data will be collected by distributing questionnaires to 200 respondents with the characteristics of men and women aged 18-60 years, residing in Surabaya, and at least having bought at Watsons offline store 2 times in the last 3 months. In this study the results show that the variables that have a significant positive effect on Emotions are Senses, Interior Design, Signage, Atmospherics, Staff, The Visitor Himself / Herself and those that do not have a significant effect are Facilities and Other Visitor's Behavior. Then Emotions has a significant positive effect on Satisfaction and Satisfaction has a significant positive effect on Customer Loyalty. Has a significant effect on repurchase intention with the coefficient of regulation of 0.661 and $C$. $R$ value of 9,420 .
\end{abstract}

Keywords: Senses, Interior Design, Signage, Facilities, Atmospherics, Staff, Other Visitor's Behaviour, The Visitor Himself/Herself, Emotions, Satisfaction, Customer Loyalty

\section{Introduction}

The retail industry plays an important role in the business world. Retail is the foundation of the business cycle which is part of business activities in selling goods or services directly to end consumers with the aim of being able to satisfy their wants and needs. For consumers, retail has a function as a provider of various products so that consumers can choose products according to their needs and desires. Today's retail is not what it used to be, with a good management system, changes in people's selective shopping patterns and a change in consumer perspective, retail that was originally traditional has begun to change into modern retail. Referring to Presidential Regulation Number 112 of 2007, traditional retail is a small and medium scale retailer, and in the buying and selling process it can be through bargaining. Modern retail has a higher demand compared to traditional retail because modern retail has a complete and comfortable shopping experience, which is not only for shopping, but also as a means of recreation, entertainment and life style (https://www.validnews.id, downloaded on February 7, 2020).

The first modern retailer that was present in Indonesia was the Sarinah Department Store which was founded in 1962 which then continued to grow until the 1980s. Then in the early 1990s, foreign retailers in 
Indonesia began to enter, namely Sogo, which is the largest retailer in Japan. When the government removed the retail business from the negative list for foreign investment by issuing Presidential Decree No. 99 of 1998, finally modern retail in Indonesia experienced rapid growth, where before the Presidential Decree was issued the number of foreign retailers in Indonesia was very limited. In 2015, AT Kearney noted that Indonesia's retail business was ranked 12th in the world in the Global Retail Development Index (GRDI). This is the highest retail growth rate Indonesia has achieved in the index since 2001, where total retail sales grew by $14.5 \%$. AT Karney noted that the retail market in Indonesia in 2015 reached USD326 billion or valued at IDR 4,306 trillion. (https://ekbis.sindonews.com, downloaded on February 5, 2020).

In the era of globalization, there will be many changes that will continue to occur, so that retail business owners must be able to anticipate them. Retail owners to these changes must adapt quickly and be responsive. One way to stay competitive in these changes is to make new innovations. These innovations will be better if they are adjusted to current trends, for example according to the lifestyle of today's society. Increasingly tighter competition in the retail business makes retail business entrepreneurs compete with each other to try to attract consumers' attention in various ways, such as improving service quality, increasing a comfortable experience in shopping, improving the atmosphere or making discounts (https: // www. journal.id, downloaded on February 5, 2020).

The retail business in general has various types, including specialty stores, department stores, supermarkets, convenience stores, discount stores, off-price stores, superstores and catalog show rooms. One of the fast growing retail businesses in Indonesia is a specialty store. A specialty store is a special store that sells a narrow product line with a variety of goods contained in the line, such as a drugstore (Watsons), a bookstore (Gramedia), a sporting goods shop (Sport Station), a cake shop (Bon Ami), and shoe store (Nike). In this case, retail tries to serve consumers from one or a small number of market segments by providing special products (https://jojonomic.com, downloaded on February 7, 2020).

Drugstore is a retail that sells a variety of health and beauty products (personal care), such as medicines, food supplements, vitamins, and digestive detoxification products for physical health from children to adults, hair care, skin care, hair care, cosmetics, which consumers can choose and find the product they are looking for when shopping, but can also ask existing employees for help. In Indonesia, there are several health and beauty retailers or what is commonly known as drugstores, which are aggressively expanding in malls or shopping centers. Some of them are PT Duta Intidaya Tbk. (DAYA), the manager of the Watsons network, PT Hero Supermarket Tbk. (HERO) managing the Guardian network, and PT Matahari Putra Prima Tbk (MPPA) managing the Boston network (https://ekonomi.bisnis.com, downloaded on February 7, 2020).

In 2017, the retail industry in Indonesia experienced complaints and tended to decline, where previously in 2015 in Indonesia the modern retail industry experienced an average growth of $10.8 \%$. The Aprindo Association said that the factors that influenced the decline in retail industry growth in 2017 included high inflation in the first six months of 2017, changes in shopping behavior where previously people shopped at retail stores directly (offline) turned into shopping through technology, namely through an online application (online store). Apart from that, another factor is that people tend to delay purchases or refrain from shopping (https://www.cnnindonesia.com, downloaded on February 10, 2020).

This complaint has an impact on the decline in sales received by several retail companies in Indonesia, one of which is PT. Matahari Putra Prima Tbk (MPPA). PT Matahari Putra Prima Tbk (MPPA) recorded sales for the first quarter of 2017 amounting to $\mathrm{Rp} 3.10$ trillion. This sales decreased $3.53 \%$ when compared to the same period in 2016 amounting to IDR 3.21 trillion. As of December 31, 2016, MPPA operates 299 outlets throughout Indonesia (115 Hypermart, 3 SmartClub, 26 Foodmart, 109 Boston Health and Beauty and 46 FMX). As of the end of 2017, MPPA operates a total of 259 stores throughout Indonesia (113 Hypermart outlets, 4 SmartClubs, 25 Foodmart, 102 Boston Health \& Beauty, and 15 FMX). So it can be concluded that Boston Health \& Beauty is in the second position of most retail closures after FMX, which is 7 stores in 1 year (https://economy.okezone.com, https://tirto.id, downloaded on 7 February 2020). 
In contrast to PT. Duta Intidaya Tbk. (DAYA) the manager of the Watsons Indonesia network. PT. Duta Intidaya Tbk. (DAYA) has successfully adapted and adjusted its business strategy to the circumstances that have occurred. Watsons is a leading health and beauty product retailer in Asia which operates 7500 retail stores and 1500 pharmaceutical retail stores in Asian and European markets, including Indonesia. This company is part of the A.S Watsons Group, one of the largest groups in Hong Kong with the Watsons brand, your personal store. Watsons entered Indonesia in 2005 and opened its first retail in 2006 at Pondok Indah Mall 2. In the midst of a decline in people's purchasing power in 2017, Watsons in Indonesia remains competitive with a significant increase in the market. Watsons was able to make large-scale expansion with the opening of Watson outlets in a marathon in Bandung, starting from the Trans studio Mall, Carrefour Kiara Condong, Paskal 23, and most recently Watsons Paris Van Java. In total Watson operates 80 outlets throughout Indonesia.

According to PT. Duta Intidaya Tbk. (DAYA), the decline in people's purchasing power is not due to people holding back expenses, but a change in spending methods. Therefore, Watsons in overcoming market complaints, he continues to make new innovations and expansions to increase sales. The innovation made is that Watsons continues to update goods according to the needs and demands of consumers who also continue to adapt to market trends. One example of a trend that Watsons took in 2017 was importing products from Korea and Japan because this has become a trend among generation Y or millennials. So that maintaining the sales scale by choosing the generation Y or millennial concept is one solution (https://www.ayobandung.com, downloaded on February 5, 2020).

\begin{tabular}{|c|c|c|c|c|c|}
\hline No & Drugstore & Sale (2017) & Rasio & Year & $\begin{array}{c}\text { Number } \\
\text { of Outlets } \\
(\mathbf{2 0 1 7})\end{array}$ \\
\hline 1 & $\begin{array}{c}\text { PT Hero } \\
\text { Supermarket } \\
\text { Tbk (Guardian) }\end{array}$ & $\begin{array}{c}\text { Rp 2.174.000.000.000 } \\
\text { including IKEA dan } \\
\text { Guardian }\end{array}$ & $10 \%$ & 1990 & 250 \\
\hline 2 & $\begin{array}{c}\text { PT Duta } \\
\text { Intidaya Tbk } \\
\text { (Watsons) }\end{array}$ & Rp 363.000.000.000 & $29,9 \%$ & 2006 & 80 \\
\hline 3 & $\begin{array}{c}\text { PT Matahari } \\
\text { Putra Prima } \\
\text { Tbk (Boston) }\end{array}$ & Rp 70.000.000.000 & $2,8 \%$ & 2002 & 102 \\
\hline
\end{tabular}

Source: https://www.watsons.biz.id, www.hero.co.id, mppa.co.id, data processed on March 19, 2020.

Table 1.1 shows the intense competition among moderndrugstores in Indonesia. It can be seen that the number of Guardian outlets and sales is higher than Watsons, but if seen from the sales growth ratio, Watsons is still higher than Guardian and Boston, where the growth ratio of Watsons in 2017 is $29.9 \%$ while Guardian is $10 \%$ and Boston is 2. , $8 \%$. Therefore, Watsons needs to always improve customer loyalty so that it can continue to survive in the drugstore market.

In addition, in the first quarter of 2019, Watsons' revenue growth in Indonesia continued to increase to $\mathrm{Rp} 75.39$ billion and continued to expand to 120 retailers and targets to become 150 retailers by the end of 2019. This revenue growth occurred due to skin care products, which became the largest market. and growing rapidly throughout 2018. This is driven by the needs of people who want to have a better appearance and are driven by the beauty blogger / influencer factor that affects people's purchasing power (https://industri.kontan.co.id, https: // lifestyle .kompas.com, downloaded on February 5, 2020). So it is very important for Watsons to always increase customer loyalty in the midst of competitive drugstore competition. Therefore, this study will focus on the analysis of the factors that affect Watsons' customer loyalty in Surabaya. 


\section{Litterature Review}

\subsection{Theories and Hypotheses}

\subsubsection{Senses}

According to Hulten et al. (2009), senses are the five human senses consisting of smell, hearing, sight, taste and touch. According to Xie and Sun (2018), senses is creating sensory experiences through various senses such as sight, hearing, touch, smell, and space and temperature, so that this sensory experience will affect the customer's emotions. Meanwhile, according to Hulten (2011), senses are sensory experiences that are defined as customer perceptions of goods or services in the service process. The same thing was said by Haase et al. (2018), senses can be defined as a customer evaluation of an object that determines the level of attraction of the object to human senses.

Hypothesis 1: Senses has a positive and significant effect on Emotions.

\subsubsection{Interior Design}

According to Cho and Shu (2020), interior design is planning, designing, creating, and building space for various activities. Meanwhile, according to Liang and Lee (2018), interior design is room design that pays attention to managing decoration styles, colors, and accessories. According to Walter and Edvardsson (2012), interior design is a physical shop environment that has several elements, consisting of furniture, decoration, space and color. Furthermore, according to Ayalp et al. (2016), interior design is room planning that has an important role in influencing customer perceptions.

Hypothesis 2: Interior Design has a positive and significant effect on Emotions.

\subsubsection{Signage}

According to the Oxford Advance Learner Dictionary of Current English, signage is providing a warning or information to direct someone to something through a word or words, design, etc. on a plate or a board. Meanwhile, according to Pegler (2012), signage is a graphic sign which can be in the form of an image, pictograph, logo, or typeface that has an element of lifestyle. Views that have a lifestyle element will create passion and pleasure (Damminga et al., 2012). In other words signage will affect emotions. According to Bauer et al. (2012), signage is a sign that provides information effectively in reaching consumers in a short time.

Hypothesis 3: Signage has a positive and significant effect on Emotions.

\subsubsection{Facilities}

According to Ariafar et al. (2011), facilities are the efficient arrangement of equipment layout in the shop from all existing resources so that customers can use the space in the facility. According to Mohan et al. (2013), facilities are a store layout that has an attractive appearance and makes it easy for customers to move and find the products needed or desired. According to Aghazadeh (2005), facilities are a layout that aims to present a variety of products in an effective and positive way. A good layout can make shopping more enjoyable, reduce stress felt in shopping, and evoke positive emotions (Baker et al., 2002).

Hypothesis 4: Facilities has a positive and significant effect on Emotions. 


\subsubsection{Atmospherics}

According to Roschk et al. (2017), atmospherics are various elements of a store environment that affect consumer perceptions, quality and value, as well as customer willingness to buy. The elements of the store environment in question are music, lighting, color, cleanliness, layout, temperature and aroma to influence customer emotions, which in turn affect shopping behavior (Oakes and North, 2008; Roschk et al., 2017; Soars, 2009) ; Michel et al., 2017; Spence et al., 2014). According to Yoon (2013), atmosphere is a factor that can encourage customers to make unplanned purchases. Following Vukadin et al. (2016), artistic elements in retail atmosphere provide a new source of hedonic satisfaction for customers.

Hypothesis 5: Atmospherics has a positive and significant effect on Emotions.

\subsubsection{Staff}

According to Albrecht et al. (2016), staff is someone who is at the forefront of having a positive appearance and facial expression so that it affects customer perceptions. According to Erkmen and Hancer (2019), staff is someone who is willing to help customers in providing appropriate and fast services, as well as services that make customers feel comfortable when interacting. Meanwhile, according to Chen et al. (2015), staff is someone who has knowledge of a product or service and is willing to help customers, so that this can affect the customer's positive and negative emotions, and according to Norfolk et al. (2007), staff is someone who interacts with customers through verbal and nonverbal communication.

Hypothesis 6: Staff has a positive and significant effect on Emotions.

\subsubsection{Other Visitor's Behaviour}

According to Brocato et al. (2012), other visitor's behavior is another customer who is in a service facility simultaneously with an unknown customer or main customer. Meanwhile, according to Erkmen and Hancer (2019), other visitor's behavior is another customer who has a good appearance, wears appropriate clothes and behaves positively as a real attribute that affects the emotions of the main customer. According to Karaosmanoglu et al. (2011) stated that other visitor's behavior is the influence of other customers through attitudes and behaviors that affect company outcomes based on emotional ties. Meanwhile, according to Tomazelli et al. (2017), other visitor's behavior is a factor that can create customer satisfaction or dissatisfaction with the purchase experience.

Hypothesis 7: Other Visitor's Behaviour has a positive and significant effect on Emotions.

\subsubsection{The Visitor Himself/Herself}

Since the 1990s, many researchers have engaged themselves to study service experiences (Bitner, 1992; Grace and O'Cass, 2004). Therefore, according to Ryu and Jang (2008), the visitor himself / herself can be defined as a self who is a visitor or customer to experience service, both cognitive knowledge and pleasure. According to Chang and Horng (2010), the visitor himself / herself who craves cognitive knowledge and pleasure is a very important component of the experience, according to Hollebeek et al. (2014), the visitor himself / herself can be defined as customer engagement, where the cognitive, emotional, and behavioral activities of 
individual customers towards goods or services. According to Grillo and Damacena (2015), the visitor himself / herself is described as the level of pleasure and interest of individual customers towards goods or services.

Hypothesis 8: The Visitor Himself/Herself has a positive and significant effect on Emotions.

\subsubsection{Emotions}

According to Vakeel et al. (2018), emotions are defined as positive or negative reactions that arise as a result of positive or negative experiences felt by customers. According to Porcherot et al. (2010), emotions can be defined as hedonic valence in terms of pleasant emotions, such as happiness and relaxation, and unpleasant emotions, such as fear, anxiety. According to Tomkins Institute (2014), emotions are an essential human trait that affects customer actions and behavior. According to Prayag et al. (2013), emotions are a fundamental role in the pre-purchase stage, where emotions can motivate customers and influence decisions to buy goods and services.

Hypothesis 9: Emotions has a positive and significant effect on Satisfaction.

\subsubsection{Satisfaction}

According to Anggraeni et al. (2016), satisfaction can be defined as customer attitude that is formed when the product or service offered meets expectations. The same thing is also expressed by Rai (2013), satisfaction can be defined as the conformity of a customer's subjective expectations with the actual suitability obtained from a product or service. According to Gupta and Bansal (2012), satisfaction is a customer's feeling or assessment of a product or service after they use it. Meanwhile, according to Solomon (2011), satisfaction is a person's overall attitude about a product after making a purchase. Satisfaction in conceptualization is generally subjective because it is based on established standards, which can be expectations, valued values and beliefs (Sirgy, 2012) .. (2016), artistic elements in retail atmospherics provide a new source of hedonic satisfaction for customers.

\section{Hypothesis 10: Satisfaction has a positive and significant effect on Customer Loyalty.}

\subsection{Research Model}

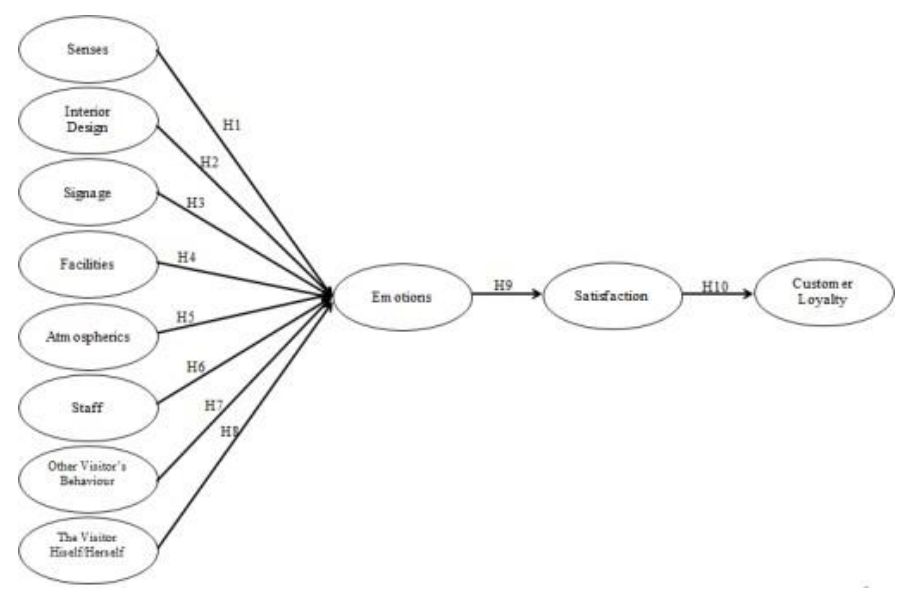

Figure 2.1: The Framework of Research Model 


\section{Research Methods}

Population is a generalization area which not only consists of subjects, but also objects that have certain characteristics and qualities that the researcher determines to be investigated and then conclusions are drawn (Sugiyono, 2008). The population used in this study were all Watsons customers in Surabaya. The population used is the customer with the characteristics of male and female aged between 18-60 years, namely early adulthood. Where users at that age are assumed to be able to think well in filling out the questionnaire, so that the data obtained is valid. Residing in Surabaya and at least buying at Watsons offline store 2 times in the last 3 months. According to Ferdinand (2002), the sample has several size guidelines, including 100-200 samples for Maximum Likelihood Estimation, depending on the number of parameters estimated, the guideline is 5-10 times the number of parameters estimated, and depending on the number of indicators used in all variables latent. This study uses as many as 40 indicators, so that 200-400 respondents is the minimum number of samples that will be needed in this study. The sample to be used in this study were 210 respondents. In this study, data collection will be carried out by distributing questionnaires. As previously explained that this study uses primary data, so the respondent will be adjusted according to the characteristics of the sample. In this study, the questionnaire will be distributed to Watsons customers in Surabaya. The questionnaire is given to Watsons customers in Surabaya who have shopped at Watsons for at least the last three months. The questionnaire in this study will be divided into two parts. The first part is for adjusting the characteristics of respondents in filling out a questionnaire containing general information questions related to the respondent. While the second part contains several statements related to the research that will be discussed, namely analyzing the influence of senses, interior design, signage, facilities, atmosphere, staff, other visitor's behavior, the visitor himself / herself on customer loyalty through emotions and satisfaction. Filling in the questionnaire will be done directly, where the respondent will fill in directly where the respondent is located. Then the researcher will make a selection from the results of filling out the respondent's questionnaire. The questionnaire that was selected and passed the selection will be further processed by the researcher by tabulating the data, where the researcher will recap all the results of the respondent's assessment. The next step that the researcher will do is test the model using AMOS version 22.0 software. To facilitate data collection, the measuring instrument to be used is the Likert Scale. The questions on the questionnaire are made using a numerical scale of 1-5 to get data that is interval, where the value is 1 for strongly disagree and a scale of 5 is for strongly agreeing.

\section{Result and Discussion}

\subsection{Assessment of Measurement Model}

Table 4.1: Regression Weights Full Structural Equation Model

\begin{tabular}{|lcc|ccc|}
\hline & & & Estimate & S.E. & C.R. \\
\hline Em & $<---$ & Se &, 227 &, 069 & 3,294 \\
Em & $<---$ & Sig &, 321 &, 094 & 3,424 \\
Em & $<---$ & Fac &, 051 &, 059 &, 864 \\
Em & $<---$ & Atm &, 309 &, 091 & 3,402 \\
Em & $<---$ & St &, 210 &, 088 & 2,390 \\
Em & $<---$ & OVB &, 054 &, 062 &, 870 \\
Em & $<---$ & TVH &, 451 &, 141 & 3,202 \\
Em & $<---$ & ID &, 313 &, 140 & 2,236 \\
Em & $<---$ & Em &, 906 &, 164 & 5,517 \\
CL & $<---$ & Sa &, 946 &, 174 & 5,437 \\
\hline
\end{tabular}




\begin{tabular}{|c|c|c|c|c|c|}
\hline & & & Estimate & S.E. & C.R. \\
\hline $\mathrm{X} 11$ & $<--$ & Sig & 1,000 & & \\
\hline $\mathrm{X} 10$ & $<--$ & Sig & 1,037 & ,260 & 3,996 \\
\hline $\mathrm{X} 9$ & $<--$ & Sig & ,897 & ,256 & 3,504 \\
\hline $\mathrm{X} 14$ & $<--$ & $\mathrm{Fac}$ & 1,000 & & \\
\hline $\mathrm{X} 13$ & $<---$ & $\mathrm{Fac}$ & 1,331 & ,443 & 3,003 \\
\hline $\mathrm{X} 12$ & $<--$ & Fac &, 800 & ,209 & 3,824 \\
\hline $\mathrm{X} 17$ & $<--$ & Atm & 1,000 & & \\
\hline $\mathrm{X} 16$ & $<--$ & Atm & 1,328 &, 341 & 3,895 \\
\hline $\mathrm{X} 15$ & $<--$ & Atm & ,692 & ,197 & 3,503 \\
\hline $\mathrm{X} 20$ & $<---$ & $\mathrm{St}$ & 1,000 & & \\
\hline X19 & $<---$ & $\mathrm{St}$ & 1,262 & ,308 & 4,098 \\
\hline $\mathrm{X} 18$ & $<--$ & St & 1,188 & ,252 & 4,720 \\
\hline $\mathrm{X} 21$ & $<---$ & St &, 740 & ,191 & 3,864 \\
\hline $\mathrm{X} 22$ & $<--$ & $\mathrm{St}$ & ,906 & ,246 & 3,682 \\
\hline $\mathrm{X} 23$ & $<--$ & $\mathrm{St}$ & ,928 & ,254 & 3,661 \\
\hline $\mathrm{X} 26$ & $<--$ & OVB & 1,000 & & \\
\hline $\mathrm{X} 25$ & $<--$ & OVB & ,940 & ,410 & 2,291 \\
\hline $\mathrm{X} 24$ & $<--$ & OVB &, 471 & , 160 & 2,935 \\
\hline $\mathrm{X} 29$ & $<--$ & TVH & 1,000 & & \\
\hline $\mathrm{X} 28$ & $<--$ & TVH & 1,246 & ,372 & 3,348 \\
\hline $\mathrm{X} 27$ & $<---$ & TVH & 1,398 & ,411 & 3,405 \\
\hline X30 & $<--$ & TVH & 1,029 & ,283 & 3,637 \\
\hline X3 & $<--$ & $\mathrm{Se}$ & 1,000 & & \\
\hline $\mathrm{X} 2$ & $<--$ & $\mathrm{Se}$ & ,993 & ,225 & 4,412 \\
\hline $\mathrm{X} 1$ & $<--$ & $\mathrm{Se}$ & ,767 & , 186 & 4,114 \\
\hline $\mathrm{X} 4$ & $<---$ & $\mathrm{Se}$ & ,927 & ,200 & 4,640 \\
\hline Y1 & $<---$ & $\mathrm{Em}$ & 1,000 & & \\
\hline Y2 & $<--$ & $\mathrm{Em}$ & 1,344 & ,203 & 6,624 \\
\hline Y3 & $<--$ & Em & 1,225 & , 190 & 6,455 \\
\hline Y4 & $<--$ & $\mathrm{Sa}$ & 1,000 & & \\
\hline Y5 & $<--$ & $\mathrm{Sa}$ & ,923 & , 175 & 5,282 \\
\hline Y6 & $<--$ & $\mathrm{Sa}$ & ,951 & , 176 & 5,409 \\
\hline Y7 & $<--$ & CL & 1,000 & & \\
\hline Y8 & $<--$ & $\mathrm{CL}$ & 1,333 & ,224 & 5,950 \\
\hline Y9 & $<--$ & $\mathrm{CL}$ & 1,402 & ,218 & 6,427 \\
\hline Y10 & $<--$ & CL & 1,418 & ,247 & 5,749 \\
\hline X7 & $<--$ & ID & 1,000 & & \\
\hline X6 & $<---$ & ID & 1,352 & ,461 & 2,933 \\
\hline X5 & $<---$ & ID & 1,082 & ,354 & 3,058 \\
\hline $\mathrm{X} 8$ & $<---$ & ID & 1,245 & ,392 & 3,174 \\
\hline
\end{tabular}

Source: Text Output AMOS 22.0 (2020) 
The table shows the C.R value of each influence between variables. The causality effect that exists between the variables Senses to Emotions, Signage to Emotions, Atmospherics to Emotions, Staff to Emotions, The Visitor Himself / Herself to Emotions, Interior Design to Emotions, Emotions to Satisfaction and Satisfaction with Customer Loyalty has a CR value above 2.00, which means has a significant positive effect. Meanwhile, the causal relationship that occurs between the Facilities variable towards Emotions and Other Visitor's Behavior on Emotions does not have a significant relationship because the C.R value is below 2.00, which is 0.864 for the relationship of the Facilities variable to Emotions and 0.870 for the relationship between Other Visitor's Behavior on Emotions.

\subsection{Hypotheses Testing}

Table 4.2: Summary of Testing Results.

\begin{tabular}{|l|c|}
\hline Hypotheses & Analysis \\
\hline H1: Senses to Emotions & Accepted \\
\hline H2: Interior Design to Emotions & Accepted \\
\hline H3: Signage to Emotions & Accepted \\
\hline H4: Facilities to Emotions & Rejected \\
\hline H5: Atmospherics to Emotions & Accepted \\
\hline H6: Staff to Satisfaction & Accepted \\
\hline H7: Other Visitor's Behaviour to Emotions & Rejected \\
\hline H8: The Visitor Himself/Herself to Emotions & Accepted \\
\hline H9: Emotions to Satisfaction & Accepted \\
\hline H10: Satisfaction to Customer Loyalty & Accepted \\
\hline
\end{tabular}

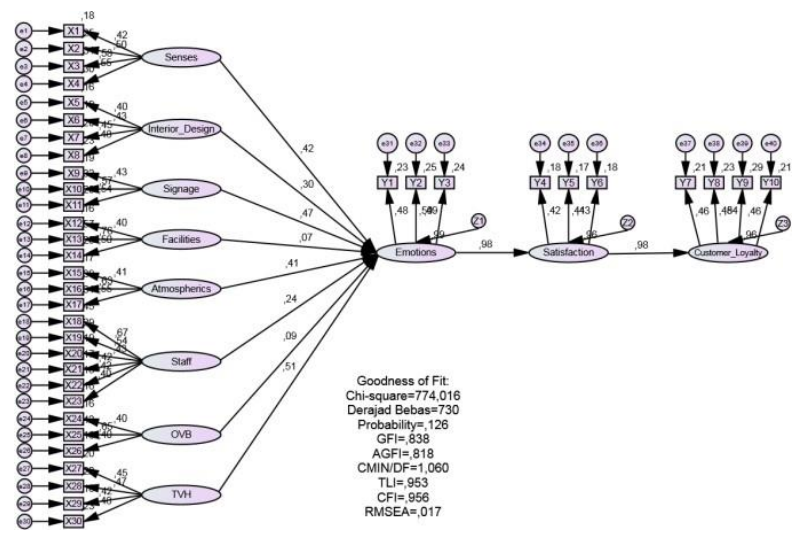

Figure 4.1 Full Structural Equation Model

\subsection{Discussion}

\subsubsection{The effect of Senses toward Emotions}

The estimation parameters between Senses and Emotions show significant results in a positive direction with a value of regression coefficient of 0.422 with a standard hypothesis that can be accepted that is C.R. $\geqslant \pm 2.00$ 
with a significance level $<0.05(5 \%)$, it can be said that hypothesis 1 (H1) is accepted. One of the elements that has an influence in increasing the Emotions variable is Senses. To increase Senses, Watsons had to increase the room temperature by controlling the air conditioner every day and installing a humidifier. Furthermore, Watsons needs to maintain the aroma of the room by installing an automatic air freshener, which through this air freshener can provide a soothing and pleasant aroma for customers when shopping. Furthermore, you can improve the background music by playing trending music or you can create a trending shop theme once a month accompanied by appropriate music, for example the theme of Christmas, New Year, Eid. And finally, increase the volume of the music by installing more sophisticated speakers, where the volume can be adjusted easily via the remote control, and Watsons can create a room design that has walls with sound reflections that can be well suppressed.

\subsubsection{The effect of Customer Service toward Emotions}

The estimation parameters between Interior Design and Emotions show significant results in a positive direction with a value of regression coefficient of 0.405 with a standard hypothesis that can be accepted that is C.R. $\geqslant \pm 2.00$ with a significance level $<0.05(5 \%)$, it can be said that hypothesis 2 (H2) is accepted. One of the elements that has an influence in increasing the Emotions variable is Interior Design. To improve Interior Design, Watsons can provide a survey of its customers about what facilities need to be added to make customers feel more comfortable and satisfied. In addition, Watsons can maintain existing furniture designs and keep abreast of trends, so that it can still be a customer pleasure. Furthermore, increasing the existing decoration style according to the current generation, namely millennials. Millennials are very close to technology, so Watsons can create an instagramable decoration style, this will attract the attention of customers to come, buy, maybe even take pictures and share them through social media. And lastly, enhancing the combination of uniform design colors with decoration and furniture design styles. And can do regular painting and make up-to-date designs.

\subsubsection{The effect of Signage toward Emotions}

The estimation parameters between Signage and Interior Design show significant results in a positive direction with a value of regression coefficient of 0.473 with a standard hypothesis that can be accepted that is C.R. $\geqslant \pm 2.00$ with a significance level $<0.05(5 \%)$, it can be said that hypothesis $3(\mathbf{H 3})$ is accepted. One of the elements that has an influence in increasing the Emotions variable is Signage. In order to increase Signage, Watsons must maintain the division of the Watsons area as it is easily understood by Watsons customers. Furthermore, the division of areas owned by Watsons is good in making it easier for customers to find the desired product so that it needs to be maintained. And finally, maintaining the existing logo and being able to put up logo signs in places that customers can easily see, and Watsons can add LED TVs which contain short videos about information on how customers can find Watsons locations from the mall entrance to searching for products that are available. via the area division sign.

\subsubsection{The effect of Facilities toward Emotions}

The estimation parameters between Facilities and Emotions show significant results in a positive direction with a value of regression coefficient of 0.072 with a standard hypothesis that can be accepted that is C.R. $\geqslant \pm 2.00$ with a significance level $<0.05(5 \%)$, it can be said that hypothesis $4(\mathbf{H 4})$ is rejected. One of the elements that has an influence in increasing the Emotions variable is Facilities. To increase Facilities, Watsons must maintain the product arrangement that Watsons has as it is considered very good by customers. 
Furthermore, the Watsons layout is considered good in making it easier to find the product that Watsons customers want, so Watsons needs to maintain it by doing a customized layout or arrangement of shelves based on the type of product. And lastly, increasing the arrangement of new products through the front shelf with an attractive decoration so that it will attract the attention of customers. New product arrangement can be arranged by category, for example by country of manufacture, product type, price, color. And the styling of a new product can be added with a look that introduces the product so that it helps in attracting positive emotions from the customer.

\subsubsection{The effect of Atmospherics toward Emotions}

The estimation parameters between Atmospherics and Emotions show significant results in a positive direction with a value of regression coefficient of 0.406 with a standard hypothesis that can be accepted that is C.R. $\geqslant \pm 2.00$ with a significance level $<0.05(5 \%)$, it can be said that hypothesis 5 (H5) is accepted. One of the elements that has an influence in increasing the Emotions variable is Atmospherics. To improve Atmospherics, Watsons must improve the atmosphere of the room by updating the shop design according to the theme or season periodically so that customers don't feel bored when shopping, for example Watsons can install a store design with Christmas equipment and Christmas trees during the Christmas season. Furthermore, the cleanliness of the room owned by Watsons is considered very good by Watsons customers so that Watsons needs to maintain it by exercising control every day. And finally, Watsons can maintain shop lighting by always checking or controlling which part of the lamp has started to dim and replacing the lamp. And can improve it by replacing their ordinary lamps with sophisticated lamps, where the light from these lamps can be adjusted the amount of brightness and intensity easily.

\subsubsection{The effect of Atmospherics toward Staff}

The estimation parameters between Atmospherics and Staff show significant results in a positive direction with a value of regression coefficient of 0.244 with a standard hypothesis that can be accepted that is C.R. $\geqslant \pm 2.00$ with a significance level $<0.05(5 \%)$, it can be said that hypothesis 6 (H6) is accepted. One of the elements that has an influence in increasing the Emotions variable is Staff. To increase staff, Watsons can provide direction to employees on how to greet customers in a polite tone, convey product information in words that are polite and easy to understand. Then Watsons can maintain service standards and continue to provide direction every day before work to every employee to always look neat, for example clothes always look neat and clean and female employees can wear makeup to make them look attractive. Furthermore, Watsons can provide training to every employee on how to behave well or how to treat customers well. Watsons can also provide regular training to employees regarding information and benefits of the products being sold, especially new products so that this will increase employee knowledge about the products being sold and customers will find it easier to attract customer emotions to make purchases. Then give direction to each employee about how to serve customers with a friendly face, for example greeting customers with a smile. And finally, increasing the active role of employees, where employees can offer assistance before customers ask questions.

\subsubsection{The effect of Other Visitor's Behaviour toward Emotions}

The estimation parameters between Other Visitor's Behaviour and Emotions show significant results in a positive direction with a value of regression coefficient of 0.085 with a standard hypothesis that can be accepted that is C.R. $\geqslant \pm 2.00$ with a significance level $<0.05(5 \%)$, it can be said that hypothesis 7 (H7) is rejected. One of the elements that has an influence on increasing the Emotions variable is Other Visitor's Behavior. To improve Other Visitor's Behavior, Watsons can maintain the good behavior of other visitors by 
providing quotes in the shop room related to customer habits or behavior, so that when customers shop, they can read these quotes. Furthermore, publish customer photos when shopping at Watsons on social media, such as Instagram. This will help other customers when shopping to Watsons to dress appropriately. And finally, increase the fun of customers by holding a mini game that requires a minimum of 4 customers, where through the mini game customers can get a small prize if they win. Dan Watsons can implement a strategy to provide cheaper product prices if buying in groups, where a group of at least ten customers.

\subsubsection{The effect of The Visitor Himself/Herself toward Emotions}

The estimation parameters between The Visitor Himself/Herself and Emotions show significant results in a positive direction with a value of regression coefficient of 0.508 with a standard hypothesis that can be accepted that is C.R. $\geqslant \pm 2.00$ with a significance level $<0.05(5 \%)$, it can be said that hypothesis 8 (H8) is accepted. One of the elements that has an influence in increasing the Emotions variable is The Visitor Himself / Herself. In order to improve The Visitor Himself / Herself, Watsons must maintain a strategy of providing a very attractive place because the customer already has a good view. Watsons can maintain it by making modifications or renovations periodically every 2 years and holding certain events with the appropriate decoration style. Then Watsons can also improve it by providing regular training to employees, where training is given about how employees understand very correctly the information from a product so that when offering products to customers it is easier to convey it, and how employees are able to convey words clearly. so that information will be conveyed properly to customers. Furthermore, Watsons can increase the active role of employees in providing information to customers directly. Employees can explain starting from the benefits, prices, and quality so that it will increase customer knowledge well. And lastly, Watsons can put new products in areas of concern to customers, such as at the cashier or at the entrance, creating a small booth, where the booth will be dedicated to introducing new products and employees can help offer a new product tester.

\subsubsection{The effect of Emotions toward Satisfaction}

The estimation parameters between Emotions and Satisfaction show significant results in a positive direction with a value of regression coefficient of 0.981 with a standard hypothesis that can be accepted that is C.R. $\geqslant \pm 2.00$ with a significance level $<0.05(5 \%)$, it can be said that hypothesis 9 (H9) is accepted. One of the elements that has an influence in increasing the Satisfaction variable is Emotions. To increase Emotions, Watsons can increase it by holding an event every month, where in the event customers can get souvenirs or prizes by playing games or making purchases with a certain minimum spending. Furthermore, Watsons can maintain the services provided in making customers continue to have more interest in the shopping experience at Watsons. And finally, improving the quality of service that Watsons has provided to customers, starting from the design, decoration style, layout, the way employees serve, and product arrangement so that customers feel happy and have a pleasant shopping experience.

\subsubsection{The effect of Satisfaction toward Customer Loyalty}

The estimation parameters between Customer Loyalty and Satisfaction show significant results in a positive direction with a value of regression coefficient of 0.978 with a standard hypothesis that can be accepted that is C.R. $\geqslant \pm 2.00$ with a significance level $<0.05(5 \%)$, it can be said that hypothesis 10 (H10) is accepted. One element that has an influence in increasing the Customer Loyalty variable is Satisfaction. To increase Satisfaction, Watsons must maintain the services provided because Watsons has been satisfying 
customers well. Furthermore, adding services in the form of free consultations, both regarding diseases and skin types, making it easier for customers to find suitable products. This will increase customer satisfaction in the shopping experience. And finally, improving services such as providing bonuses in the form of vouchers or special Watsons merchandise for customers who have made a certain nominal purchase, so that this will increase Watsons customer satisfaction because it provides services that exceed expectations.

\section{Conclusion}

\subsection{Managerial Implications}

Table 5.1: Managerial Implications

\begin{tabular}{|c|c|}
\hline Current Research & Managerial Implications \\
\hline $\begin{array}{lll}\text { Senses } & \text { significantly } & \text { affected } \\
\text { Emotions. } & & \end{array}$ & $\begin{array}{l}\text { Increase the room temperature by controlling the air conditioner every } \\
\text { day and installing a humidifier. Furthermore, Watsons needs to } \\
\text { maintain the aroma of the room by installing an automatic air } \\
\text { freshener, which through this air freshener can provide a soothing and } \\
\text { pleasant aroma for customers when shopping. Furthermore, you can } \\
\text { improve the background music by playing trending music or you can } \\
\text { create a trending shop theme once a month accompanied by } \\
\text { appropriate music, for example the theme of Christmas, New Year, } \\
\text { Eid. And finally, increase the volume of the music by installing more } \\
\text { sophisticated speakers, where the volume can be adjusted easily via } \\
\text { the remote control, and Watsons can create a room design that has } \\
\text { walls with sound reflections that can be well suppressed. }\end{array}$ \\
\hline $\begin{array}{l}\text { Interior Design significantly affected } \\
\text { Emotions. }\end{array}$ & $\begin{array}{l}\text { Provide a survey of its customers regarding what facilities need to be } \\
\text { added to make customers feel more comfortable and satisfied. In } \\
\text { addition, Watsons can maintain existing furniture designs and keep } \\
\text { abreast of trends, so that it can still be a customer pleasure. } \\
\text { Furthermore, increasing the existing decoration style according to the } \\
\text { current generation, namely millennials. Millennials are very close to } \\
\text { technology, so Watsons can create an instagramable decoration style, } \\
\text { this will attract the attention of customers to come, buy, maybe even } \\
\text { take pictures and share them through social media. And lastly, } \\
\text { enhancing the combination of uniform design colors with decoration } \\
\text { and furniture design styles. And can do regular painting and make up- } \\
\text { to-date designs. }\end{array}$ \\
\hline $\begin{array}{l}\text { Signage significantly affected } \\
\text { Emotions. }\end{array}$ & $\begin{array}{l}\text { Maintains the division of Watsons owned because it is easily } \\
\text { understood by Watsons customers. Furthermore, the division of areas } \\
\text { owned by Watsons is good in making it easier for customers to find } \\
\text { the desired product so that it needs to be maintained. And finally, } \\
\text { maintaining the existing logo and being able to put up logo signs in } \\
\text { places that customers can easily see, and Watsons can add LED TVs } \\
\text { which contain short videos about information on how customers can } \\
\text { find Watsons locations from the mall entrance to searching for } \\
\text { products that are available. via the area division sign. }\end{array}$ \\
\hline
\end{tabular}




\begin{tabular}{|c|c|}
\hline $\begin{array}{l}\text { Facilities significantly affected } \\
\text { Emotions. }\end{array}$ & $\begin{array}{l}\text { Maintain Watsons' product order as it is considered very good by } \\
\text { customers. Furthermore, the Watsons layout is considered good in } \\
\text { making it easier to find the product that Watsons customers want, so } \\
\text { Watsons needs to maintain it by doing a customized layout or } \\
\text { arrangement of shelves based on the type of product. And lastly, } \\
\text { increasing the arrangement of new products through the front shelf } \\
\text { with an attractive decoration so that it will attract the attention of } \\
\text { customers. New product arrangement can be arranged by category, for } \\
\text { example by country of manufacture, product type, price, color. And } \\
\text { the styling of a new product can be added with a look that introduces } \\
\text { the product so that it helps in attracting positive emotions from the } \\
\text { customer. }\end{array}$ \\
\hline $\begin{array}{l}\text { Atmospherics significantly affected } \\
\text { Emotions. }\end{array}$ & $\begin{array}{l}\text { Periodically update the shop design according to the theme or season } \\
\text { so that customers don't feel bored when shopping, for example } \\
\text { Watsons can install a shop design with Christmas equipment and a } \\
\text { Christmas tree during the Christmas season. Furthermore, the } \\
\text { cleanliness of the room owned by Watsons is considered very good by } \\
\text { Watsons customers so that Watsons needs to maintain it by exercising } \\
\text { control every day. And finally, Watsons can maintain shop lighting by } \\
\text { always checking or controlling which part of the lamp has started to } \\
\text { dim and replacing the lamp. And can improve it by replacing their } \\
\text { ordinary lamps with sophisticated lamps, where the light from these } \\
\text { lamps can be adjusted the amount of brightness and intensity easily. }\end{array}$ \\
\hline Staff significantly affected Emotions. & $\begin{array}{l}\text { Provide direction to employees on how to greet customers in a polite } \\
\text { tone, convey product information in polite and easy-to-understand } \\
\text { words. Then Watsons can maintain service standards and continue to } \\
\text { provide direction every day before work to every employee to always } \\
\text { look neat, for example clothes always look neat and clean and female } \\
\text { employees can wear makeup to make them look attractive. } \\
\text { Furthermore, Watsons can provide training to every employee on how } \\
\text { to behave well or how to treat customers well. Watsons can also } \\
\text { provide regular training to employees regarding information and } \\
\text { benefits of the products being sold, especially new products so that } \\
\text { this will increase employee knowledge about the products being sold } \\
\text { and customers will find it easier to attract customer emotions to make } \\
\text { purchases. Then give direction to each employee about how to serve } \\
\text { customers with a friendly face, for example greeting customers with a } \\
\text { smile. And finally, increasing the active role of employees, where } \\
\text { employees can offer assistance before customers ask questions. }\end{array}$ \\
\hline $\begin{array}{l}\text { Other Visitor's Behaviour } \\
\text { significantly affected Emotions. }\end{array}$ & $\begin{array}{l}\text { Maintain good behavior of other visitors by providing quotes in the } \\
\text { shop room related to customer habits or behavior, so that when } \\
\text { customers shop, they can read these quotes. Furthermore, publish } \\
\text { customer photos when shopping at Watsons on social media, such as } \\
\text { Instagram. This will help other customers when shopping to Watsons } \\
\text { to dress appropriately. And finally, increase the fun of customers by } \\
\text { holding a mini game that requires a minimum of } 4 \text { customers, where } \\
\text { through the mini game customers can get a small prize if they win. } \\
\text { Dan Watsons can implement a strategy to provide cheaper product }\end{array}$ \\
\hline
\end{tabular}




\begin{tabular}{|c|c|}
\hline & prices if buying in groups, where a group of at least ten customers. \\
\hline $\begin{array}{l}\text { The Visitor Himself/Herself } \\
\text { significantly affected Emotions. }\end{array}$ & $\begin{array}{l}\text { Maintain a strategy of providing a very attractive place because the } \\
\text { customer already has a good view. Watsons can maintain it by making } \\
\text { modifications or renovations periodically every } 2 \text { years and holding } \\
\text { certain events with the appropriate decoration style. Then Watsons } \\
\text { can also improve it by providing regular training to employees, where } \\
\text { training is given about how employees understand very correctly the } \\
\text { information from a product so that when offering products to } \\
\text { customers it is easier to convey it, and how employees are able to } \\
\text { convey words clearly. so that information will be conveyed properly } \\
\text { to customers. Furthermore, Watsons can increase the active role of } \\
\text { employees in providing information to customers directly. Employees } \\
\text { can explain starting from the benefits, prices, and quality so that it } \\
\text { will increase customer knowledge well. And lastly, Watsons can put } \\
\text { new products in areas of concern to customers, such as at the cashier } \\
\text { or at the entrance, creating a small booth, where the booth will be } \\
\text { dedicated to introducing new products and employees can help offer a } \\
\text { new product tester. }\end{array}$ \\
\hline $\begin{array}{l}\text { Emotions significantly affected } \\
\text { Satisfaction. }\end{array}$ & $\begin{array}{l}\text { Hold an event every month, where in the event customers can get } \\
\text { souvenirs or prizes by playing games or making purchases with a } \\
\text { certain minimum shopping. Furthermore, Watsons can maintain the } \\
\text { services provided in making customers continue to have more interest } \\
\text { in the shopping experience at Watsons. And finally, improving the } \\
\text { quality of service that Watsons has provided to customers, starting } \\
\text { from the design, decoration style, layout, the way employees serve, } \\
\text { and product arrangement so that customers feel happy and have a } \\
\text { pleasant shopping experience. }\end{array}$ \\
\hline $\begin{array}{l}\text { Satisfaction significantly affected } \\
\text { Customer Loyalty. }\end{array}$ & $\begin{array}{l}\text { Maintain the service provided because Watsons has been satisfying } \\
\text { customers overall. Furthermore, adding services in the form of free } \\
\text { consultations, both regarding diseases and skin types, making it easier } \\
\text { for customers to find suitable products. This will increase customer } \\
\text { satisfaction in the shopping experience. And finally, improving } \\
\text { services such as providing bonuses in the form of vouchers or special } \\
\text { Watsons merchandise for customers who have made a certain nominal } \\
\text { purchase, so that this will increase Watsons customer satisfaction } \\
\text { because it provides services that exceed expectations. }\end{array}$ \\
\hline
\end{tabular}

\section{References}

Aghazadeh, S.-M. (2005). Layout Strategies for Retail Operations: A Case Study. Management Research News, 28(10), 31-46.

Albrecht, C.-M., Hattula, S., Wayne, T. B., \& Hoyer, W. D. (2016). Customer Response to Interactional Service Experience. Journal of Service Management, 27(5), 704-729.

Albrecht, K. (2016). Understanding the Effects of the Presence of Others in the Service Environment: a Literature Review. Journal of Business Market Management, 9(1), 541-563.

Ali, F., \& Amin, M. (2013). The Influence of Physical Environment on Emotions, Customer Satisfaction and Behavioural Intentions in Chinese Resort Hotel Industry. Toursim and Hospitality Industri, KMITLAGBA Conference Bangkok, 15-17/June, Thailand. 
Alnsour, M. S., Tayeh , B. A., \& Alzyadat, M. A. (2014). Using SERVQUAL to Assess the Quality of Service Provided by Jordanian Telecommunications Sector. International Journal of Commerce and Management, 24(3), 209-218.

Alshammari, F., \& Kim, Y. -K. (2019). Seeking and Escaping in a Saudi Arabian Festival. International Journal of Event and Festival Management.

Amorim, M., \& Saghezchi, F. B. (2014). An Investigation of Service Quality Assessments Across Retail Formats. International Journal of Quality and Service Sciences, 6(2/3), 221-236.

Andersson, M., Palmblad, S., \& Prevedan, T. (2012). Atmospherics Effects on Hedonic and Utulitarian Customers. Spring.

Anggraeni, L. D., Deoranto, P., \& Ikasari, D. M. (2016). Analisis Persepsi Konsumen Menggunakan Metode Importance Perfomance Analysis dan Customer Satisfaction Index. Jurnal Industri, Vol. 4, No. 2.

Anna, L. K. (2019, Mei 5). Watsons Targetkan Miliki 150 Toko Sampai Akhir 2019. Dipetik Februari 5, 2020, dari Kompas.com: https://lifestyle.kompas.com/read/2019/05/05/192000820/watsons-targetkanmiliki-150-toko-sampai-akhir-2019

Anselmsson, J., \& Johansson, U. (2014). A Comparison of Customer Perceived Service Quality in Discount Versus Traditional Grocery Stores. International Journal of Quality and Service Sciences, 6(4), 369386.

Ariafar, S., Ismail, N., Tang, S. H., Ariffin, M. K., \& Firoozi, Z. (2011). A Stochastic Facility Layout Model in Cellular Manufacturing Systems. International Journal of the Physical Sciences , Vol. 6(15), 3754-3758.

Arikunto, S. (2010). Prosedur Penelitian Suatu Pendekatan Praktik Edisi Revisi. Jakarta: PT. Rineka Cipta.

Ayalp, N., Yildirim, K., Bozdayi, M., \& Cagatay, K. (2016). Consumers' Evaluations of Fitting Rooms in Retail Clothing Stores. International Journal of Retail \& Distribution Management, 44(5), 524-539.

Bae, Y. H., Jun , J. W., \& Hough, M. (2016). Uses and Gratifications of Digital Signage and Relationships with User Interface. Journal of International Consumer Marketing, 28(5), 323-331.

Bagozzi, R. P., Belanche, D., Casaló, L. V., \& Flavián, C. (2016). The Role of Anticipated Emotions in Purchase Intentions. Pschology and Marketing, 33(8), 629-645.

Baker, J., \& Cameron, M. (1996). The Effects of the Service Environment on Affect and Consumer Perception of Waiting Time: An Integrative Review and Research Propositions. Journal of the Academy of Marketing Science, 24(4), 338-349.

Baker, J., Parasuraman, A., Grewal, D., \& Voss, G. B. (2002). The Influence of Multiple Store Environment Cues on Perceived Merchandise Value and Patronage Intentions. Journal of Marketing, 66(2), 120141.

Baker, M. A., \& Kim, K. (2016). Other Customer Service Failures Emotions, Impacts, and Attributions. Journal of Hospitality and Tourism Research, 42(7), 1067-1085.

Balaji, M. S., \& Chakraborti, R. (2015). Stadium Atmosphere: Scale Development and Validation in Indian Context. Journal of Indian Business Research, 7(1), 45-66.

Bartholme, R. H., \& Melewar, T. C. (2011). Remodelling the Corporate Visual Identity Construct. An International Journal, 16(1), 54-64.

Bauer, C., Dohmen, P., \& Strauss, C. (2012). A conceptual framework for backend services of contextual digital signage. Journal of Service Science Research, 4(2), 271-297.

Bella, A. (2018, Desember 6). Watsons Raih The Omni-Marketing Campaign of the Year. Dipetik Februari 5, 2020, dari Marketeers: https://marketeers.com/watsons-raih-the-omni-marketing-campaign-of-theyear/

Berndt-Morris , E., \& Chrenka, K. (2014). The Plan Behind the Scan: Using QR Codes as a Service and Marketing Tool. Library Hi Tech News, 31(10), 17-19.

Berry, L. L., Mullen, E. W., \& Carbone, L. P. (2006). Service Dues and Customer Assessment of the Service Experience: Lessons From Marketing. Academy of Management Perspectives, 20(2), 43-57. 
Biesok, G., \& Wyród-Wróbel, J. (2011). Customer Satisfaction - Meaning and Methods of Measuring. Dalam Marketing and logistic problems in the management of organization (hal. 23-41). BielskoBiała: Wydawnictwo Naukowe Akademii Techniczno-Humanistycznej w Bielsku-Białej.

Bitner, M. J. (1992). Servicescape: The Impact of Physical Surroundings on Customers and Employees. Journal of Marketing, 56(2), 57-71.

Brocato , E. D., Voorhees, C. M., \& Baker, J. (2012). Understanding the Influence of Cues from Other Customers in the Service Experience: A Scale Development and Validation. Journal of Retailing, 88(3), 384-398.

Brodie, R. J., Hollebeek, L. D., Juric, B., \& Ilic, A. (2011). Customer Engagement Conceptual Domain, Fundamental Propositions, and Implications for Research. Journal of Service Research, 14(3), 252271.

Bruwer, J., \& Thach, L. (2013). Wine Tourists' Use of Sources of Information When Visiting a USA Wine Region. Journal of Vacation Marketing, Vol. 19, No. 3, pp. 221-237.

Canniere, M. H., Pelsmacker, P. D., \& Geuens, M. (2010). Relationship Quality and Purchase Intention and Behavior: The Moderating Impact of Relationship Strength. Journal of Business and Psychology, 25(1), 87-98.

Caroline, E. (2019, Desember). Grand Opening Watsons Pakuwon Mall. Dipetik Maret 25, 2020, dari Eat Sleep Kiss: http://carolinelle.blogspot.com/2018/12/grand-opening-watsons-pakuwon-mall.html

Casidy, R., \& Wymer, W. (2016). A Risk Worth Taking: Perceived Risk as Moderator of Satisfaction, Loyalty, and Willingness-to-Pay Premium Price. Journal of Retailing and Consumer Services, 32, 189-197.

Chan, E. A., Jones, A., Fung, S., \& Wu, S. C. (2012). Nurses' perception of time availability in patient communication in Hong Kong. Journal of Clinical Nursing, 21(7-8), 1168-1177.

Chang, H. H. (2015). Which One Helps Tourists Most? Perspectives of International Tourists Using Different Navigation Aids . Toursim Geographies, 17(3), 350-369.

Chang, H. J., Cho, H. J., Turner, T., Gupta, M., \& Watchravesringkan, K. (2015). Effects of store attributes on retail patronage behaviors. Journal of Fashion Marketing and Management. An International Journal, 19(2), 136-153.

Chang, T. -Y., \& Horng, S. C. (2010). Conceptualizing Andmeasuring Experience Quality: The Customer's Perspective. The Service Industries Journal, 30(14), 2401-2419.

Chen, A., Peng , N., \& Hung, K.-p. (2015). The Effects of Luxury Restaurant Environments on Diners' Emotions and Loyalty. International Journal of Contemporary Hospitality Management, 27(2). 236260.

Cho, J. Y., \& Suh, J. (2020). Interior Design and Creativity. Reference Module in Neuroscience and Biobehavioral Pschology.

Chun Wang, J., Wang, Y. -C., \& Tai, Y. -F. (2016). Systematic Review of the Elements and Service Standards of Delightful Service. International Journal of Contemporary Hospitality Management, 28(7), 1310-1337.

Claudia, E. (2019, Agustus 19). Jojo Nomic. Dipetik Februari 7, 2020, dari 13 Jenis Bisnis Ritel agar Usahamu Cepat Maju: https://jojonomic.com/blog/ritel/

Countryman, C. C., \& Jang, S. (2006). The Effects of Atmospheric Elements on Customer Impression: The Case of Hotel Lobbies. International Journal of Contemporary Hospitality Management, 18(7), 534545.

Dahwilani, D. M. (2015, Juni 2). Pertumbuhan Ritel Indonesia 12 Peringkat Dunia. Dipetik Februari 5, 2020, dari Sindo News: https://ekbis.sindonews.com/read/1007773/34/pertumbuhan-ritel-indonesiaperingkat-12-dunia-1433163799 
Damminga, C., Wu, J., \& Johnson, K. P. (2012). The Effect of Lifestyle and Shoppable Fashion Product Displays on Consumers' Approach and Avoidance Behavior. Journal of Global Fashion Marketing, Vol. 3, No. 3, 108-118.

Dennis, C., Newman , A., Michon, R., Brakus, J. J., \& Wright, L. T. (2010). The Mediating Effects of Perception and Emotion: Digital Signage in Mall Atmospherics. Journal of Retailing and Consumer Services, 17(3), 205-215.

Dennis, C., Brakus , J. J., Gupta , S., \& Alamanos, E. (2014). The Effect of Digital Signage on Shoppers' Behavior: The Role of The Evoked Experience. Journal of Business Research, 67(11), 2250-2257.

Desra. (2019, Mei 26). Tantangan Besar yang Dihadapi Industri Retail Saat Ini . Dipetik Februari 5, 2020, dari Jurnal by Mekari: https://www.jurnal.id/id/blog/tantangan-besar-yang-dihadapi-industri-retailsaat-ini/

Djali. (2008). Skala Likert. Jakarta: Pustaka Utama.

Durianto, D. (2004). Brand Equity Ten Strategi Memimpin Pasar. Gramedia Pustaka Utama.

Dwijayanto , A., \& Tendi. (2019, November 15). Duta Intidaya (DAYA) akan redesign seluruh gerai Watsons di tahun ini. Dipetik Februari 5, 2020, dari Kontan.co.id: https://industri.kontan.co.id/news/dutaintidaya-daya-akan-redesign-seluruh-gerai-watsons-di-tahun-ini

Edvardsson, B., Enquist, B., \& Johnston, R. (2010). Design Dimensions of Experience Rooms for Service Test-Drives: Case Studies in Different Service Contexts. Journal of Service Theory and Practice, 20(4), 312-327.

Erkmen, E., \& Hancer, M. (2019). Building Brand Relationship for Restaurants An Examination of Other Customers, Brand Image, Trust, and Restaurant Attributes. International Journal of Contemporary Hospitality Management.

Faullant, R., Matzler, K., \& Mooradian, T. A. (2011). Personality, Basic Emotions, and Satisfaction: Primary Emotions in The Mountaineering Experience. Tourism Management, 32(6), 1423-1430.

Fauzi, Y. (2017, Agustus 3). Perubahan Pola Belanja Masyarakat Bukan Alasan Daya Beli Lesu. Dipetik Februari 10, 2020, dari CNN Indonesia: https://www.cnnindonesia.com/ekonomi/2017080316365692-232260/perubahan-pola-belanja-masyarakat-bukan-alasan-daya-beli-lesu

Ferdinand, A. (2002). Structural equation modeling dalam penelitian manajemen. Semarang: Badan Penerbit Universitas Diponegoro.

Fernandes, A. A. (2018). The Mediation Effect of Customer Satisfaction in Relationship Between Service Quality, Service Orientation, and Marketing Mix Strategy to Customer Loyalty. Journal of Management Development, 37(1), 76-78.

Fimela. (2018, Februari 7 ). 8 Keuntungan Menarik Jika Kamu Punya Membercard Watsons. Dipetik Maret 19, 2020, dari Fimela: https://www.fimela.com/fashion-style/read/3777817/8-keuntungan-menarikjika-kamu-punya-membercard-watsons

Ganiyu, R. A. (2017). Customer Satisfaction And Loyalty: A Study Of Interrelationships and Effects In Nigerian Domestic Airline Industry. Oradera Journal of Business and Economics, Vol. 2, No. 1, pp. 7-20.

Garaus, M., Wagner, U., \& Manzinger, S. (2017). Happy Grocery Shopper: The Creation of Positive Emotions Through Affective Digital Signage Content. Technological Forecasting and Social Change, 124, 295-305.

Gaynor, L.-G. (2009). Fashion Marketing Communications. Journal of Fashion Marketing and Management.

GoToMalls. (t.thn.). Watsons at Pakuwon Mall. Dipetik Maret 26, 2020, dari Go to Malls: https://www.gotomalls.com/malls/L0fnh4LOVNW1Dklj/pakuwonmall/stores/LcZH1ct5IQh8kyLU/watsons

Grace, D. A., \& O'Cass, A. (2004). Examining Service Experiences and Post-Consumption Evaluations. Journal of Services Marketing , 18(6), 460-461. 
Grillo, T. L., \& Damacena, C. (2015). Student Engagement: The Role of Social Influence and Locus of Control. International Journal of Management in Education, 9(4), 466-485.

Guenzi, P., Johnson, M. D., \& Castaldo, S. (2009). A Comprehensive Model of Customer Trust in Two Retail Stores. Journal of Service Management, 20(3), 290-316.

Gupta, K. K., \& Bansal, I. (2012). Development of an Instrument to Measure Interne Banking Service Quality in India. International Refereed Research Journal, 2(2), 11-25.

Haase, J., Wiedmann, K. -P., \& Labe, F. (2018). Effects of Consumer Sensory Perception on Brand Performance. Journal of Consumer Marketing.

Hadyan, R. (2019, September 2). Ritel Kesehatan \& Kecantikan Kian Agresif Ekspansi di Mal. Dipetik Februari 7, 2020, dari Ekonomi Bisnis: https://ekonomi.bisnis.com/read/20190902/12/1143591/ritelkesehatan-kecantikan-kian-agresif-ekspansi-di-mal

Hair Jr. , J. F., Black, W. C., Babin, B. J., \& Anderson, R. E. (2007). Multivariate Data Analysis, 6th Edition. New Jersey: Pearson Education Inc.

Hansen, K. V., Jensen , Ø., \& Gustafsson, I. -B. (2005). The Meal Experiences of á la Carte Restaurant Customers. Scandinavian Journal of Hospitality and Toursim, 5, 135-151.

Harmeling, C. M., Moffett , J. W., Arnold , M. J., \& Ca, B. D. (2017). Toward a Theory of Customer Engagement Marketing. Journal of the Academy of Marketing Science, 45(3), 312-335.

HERO Group. (2017). Laporan Tahunan 2017. Tangerang Selatan: PT Hero Supermarket Tbk.

Heung, V. C., \& Gu, T. (2012). Influence of Restaurant Atmospherics on Patron Satisfaction and Behavioral Intentions. International Journal of Hospitality Management, 31(4), 1167-1177.

Hollebeek, L. D., Glynn, M. S., \& Brodie, R. J. (2014). Consumer Brand Engagement in Social Media: Conceptualization, Scale Development and Validation. Journal of Interactive Marketing, 28(2), 149165.

Hulten, B. (2011). Sensory Marketing: the Multi-Sensory Brand-Experience Concept. European Business Review, 23(2), 256-273.

Hulten, B., Broweus, N., \& Van Djik, M. (2009). Sensory Marketing, Palgrave Macmillan, Basingstoke.

Io, M. -U. (2017). Understanding the Effects of Multi-Dimensional Tourism Experiences on Tourists' Positive Emotions and Satisfaction in the Context of Casino Hotels. International Journal of Culture, Tourism and Hospitality Research, 11(2), 142-156.

Joseph-Mathews, S., Bonn , M. A., \& Snepe, D. (2009). Atmospherics and Consumers' Symbolic Interpretations of Hedonic Services. International Journal of Culture, Tourism and Hospitality Research, 3(3), 193-210.

Karaosmanoğlu, E., Banu Elmadağ Baş, A., \& Zhang, J. (. (2011). The Role of Other Customer Effect in Corporate Marketing. European Journal of Marketing, 45(9/10), 1416-1445.

Kastenholz, E., Carneiro, M. J., Marques, C. P., \& Loureiro, S. M. (2018). The Dimensions of Rural Tourism Experience: Impacts on Arousal, Memory, and Satisfaction. Journal of Travel \& Tourism Marketing, 35(2), 189-201.

Keller, K. L. (2003). Strategic Brand Management: Building, Measuring and Managing Equity. New Jersey: Practice Hall.

Kenia, I., \& Huzaini, A. (2019, Agustus 14). Pasar produk perawatan kulit punya potensi berkembang. Dipetik Februari 5, 2020, dari kontan.co.id: https://industri.kontan.co.id/news/pasar-produkperawatan-kulit-punya-potensi-berkembang

Kesari, B., \& Atulkar, S. (2016). Satisfaction of Mall Shoppers: A Study on Perceived Utilitarian and Hedonic Shopping Values. Journal of Retailing and Consumer Services, 31, 22-31.

Kim, S., Chung , J. -E., \& Suh, Y. (2016). Multiple Reference Effects on Restaurant Evaluations: a CrossCultural Study. International Journal of Contemporary Hospitality Management, 28(7), 1441-1466.

Kotler, P., \& Armstrong, G. (2010). Prinsip-Prinsip Pemasaran, Jilid 1 dan 2 Edisi Kedua Belas. Jakarta: Erlangga. 
Krishna, A. (2012). An Integrative Review of Sensory Marketing: Engaging the Senses to Affect Perception, Judgment and Behavior. Journal of Consumer Psychology, 22(3), 332-351.

Kumar, I., Garg, R., \& Rahman, Z. (2010). Influence of Retail Aatmospherics on Customer Value in an Emerging Market Condition. Great Lakes Herald, 3(1), 1-13.

Lee, K., Madanoglu, M., Ha, I. S., \& Fritz, A. (2018). The Impact of Service Quality and Customer Satisfaction on Consumer Spending in Wineries. The Service Industries Journal, 1-13.

Lee, S., Manthiou, A., Jeong, M., Tang, L., \& Chiang, L. (2015). Does Consumers' Feeling Affect Their Quality of Life? Roles of Consumption Emotion and Its Consequences. International Journal of Tourism Research, 17(4), 409-416.

Lee, Y. -K., Kim , S. Y., Son, M. H., \& Lee, D. -J. (2011). Do Emotions Play a Mediating Role in the Relationship Between Owner Leadership Styles and Manager Customer Orientation, and Performance in Service Environment? International Journal of Hospitality Management, 30(4), 942952.

Liang, C. C., \& Lee, J. P. (2018). Carbon Footprint Model for Reverse Logistics of Waste Disposal in Interior Design Industry. Asia Pacific Journal of Marketing and Logistics, 40(4), 889-906.

Liao, G. -Y., Huang, H. C., \& Teng, C. -I. (2016). When Does Frustation Not Reduce Continuance Intention of Online Gamers? The Expectancy Disconfirmation Perspective. Journal of Electornic Commerce Research, 17(1), 65-79.

Lin , J.-S. C., \& Liang, H.-Y. (2011). The Influence of Service Environments on Customer Emotion and Service Outcomes. Managing Service Quality: An International Journal, 21(4), 350-372.

Lin, R. -J., Chen, R. -H., \& Chiu, K. K.-S. (2010). Customer Relationship Management and Innovation Capability: An Empirical Study. Industrial Management \& Data Systems, 101(1), 111-133.

Little, J. (2012). Transformational Tourism, Nature and Wellbeing: New Perspectives on Fitness and the Body*. Sociologia Ruralis, 52 (3), 257-271.

Lusch, . F., Dunner, P. M., \& Carve, J. R. (2011). Introduction to retailing. Mason, Ohio: South-Western Cengage Learning.

Morrison, M., Gan, S., Dubelaar, C., \& Oppewal, H. (2011). In-store Music and Aroma Influences on Shopper Behavior and Satisfaction. Journal of Business Research , 64(6), 558-564.

Mosahab, R., Mahamad, O., \& Ramayah, T. (2010). Service Quality, Customer Satisfaction and Loyalty: A Test of Mediation. International Business Research, 3(4), 72-80.

Nicholls, R., \& Mohsen, M. G. (2015). Other Customer Age: Exploring Customer Age-Difference Related CCI. Journal of Services Marketing, 29(4), 255-267.

Nordfält, J., Grewal , D., Roggeveen, A. L., \& Hill, K. M. (2014). Insights from In-Store Marketing Experiments. Shopper Marketing and the Role of In-Store Marketing, 127-146.

Oakes, S., \& North, A. C. (2008a). Reviewing Congruity Effects in the Service Environment Musicscape. International Journal of Service Industry Management, 19(1), 63-82.

Oakes , S., \& North, A. C. (2008b). Using Music to Influence Cognitive and Affective Responses in Queues of Low and High Crowd Density. Journal of Marketing Management, 24(5-6), 589-602.

Pleshko , L. P., \& Heiens, R. A. (2015). Customer Satisfaction and Loyalty in The Kuwaiti Retail Services Market: Why Are Satisfied Buyers Not Always Loyal Buyers? The International Review of Retail, Distribution and Consumer Research, 25(1), 55-71.

Porcherot , C., Delplanque, S., Raviot-Derrien , S., Calvé, B. L., Chrea , C., Gaudreau , N., et al. (2010). How Do You Feel When You Smell This? Optimization of a Verbal Measurement of Odor-Elicited Emotions. Food Quality and Preference, 21(8), 938-947.

Prayag, G., Hosany, S., \& Odeh, K. (2013). The Role of Tourists' Emotional Experiences and Satisfaction in Understanding Behavioral Intentions. Journal of Destination Marketing and Management, 2(2), 118127.

PT Duta Intidaya Tbk. (2017). Laporan Tahunan 2017. Jakarta Selatan. 
Puspita, D. (2018). Asyiknya Belanja Produk Kecantikan Di Watsons, Banyak Diskon Dan Promo Menarik Loh! Dipetik Maret 26, 2020, dari Dwipuspita: https:/www.dwipuspita.com/2019/09/belanjaproduk-kecantikan-di-watsons.html

Puspitasari , I., \& Husaini, A. (2019, Mei 1). Duta Intidaya (DAYA) jalankan dua strategi dalam bisnisnya tahun ini. Dipetik Februari 5, 2020, dari Kontan.co.id: https://industri.kontan.co.id/news/dutaintidaya-daya-jalankan-dua-strategi-dalam-bisnisnya-tahun-ini

Rahayu, E. M. (2013, September 20). Ambisi Watsons Menjadi Ritel No.1 di Asia. Dipetik Maret 19, 2020, dari SWA: https://swa.co.id/swa/headline/ambisi-watsons-menjadi-ritel-no-1-di-asia

Sirgy, M. J. (2012). The Psychology of Quality of Life: Hedonic Well-Being, Life Satisfaction, and Eudaimonia. Springer.

Sit, W. -Y., Ooi, K. -B., Lin, B., \& Chong, A. Y.-L. (2009). TQM and Customer Satisfaction in Malaysia's Service Sector. Industrial Management and Data Systems, 109(7), 957-975.

Skandrani, H., Mouelhi, N. B., \& Malek, F. (2011). Effect of Store Atmospherics on Employees' Reactions. International Journal of Retail \& Distribution Management, 39(1), 51-67.

Sugiyono. (2017). Metode Penelitian Kuantitatif, Kualitatif, dan R\&D. Bandung: Alfabeta, CV.

Sum, C. Y., \& Hui, C. L. (2009). Salespersons' Service Quality and Customer Loyalty in Fashion Chain Stores. Journal of Fashion Marketing and Management: An International Journal, 13(1), 98-108.

Tang, A. (2017, Juli 10). Watsons launches brand refresh campaign with new uniforms. Dipetik Maret 25, 2020, dari Marketing: https://old.marketing-interactive.com/watsons-new-uniform-plays-key-role-inlatest-brand-refresh-campaign/

Thakur, R. (2016). Understanding Customer Engagement and Loyalty: A Case of Mobile Devices for Shopping. Journal of Retailing and Consumer Services, 32, 151-163.

Timlin, G., \& Rysenbry, N. (2010). Design for Dementia: Improving Dining and Bedroom Environments in Care Home. London: Royal College of Art.

Tomazelli, J., Broilo, P. L., Espartel, L. B., \& Basso, K. (2017). The Effects of Store Environment Elements on Customer-to-Customer Interactions Involving Older Shoppers. Journal of Services Marketing, 31(4/5), 339-350.

Vakeel, K. A., Sivakumar, K., R., J. K., \& Dey, S. (2018). Service Failures After Online Flash Sales: Role of Deal Proneness, Attribution, and Emotion. Journal of Service Management, 29(2), 253-276.

Vukadin, A., Lemoine , J. -F., \& Badot, O. (2016). Opportunities and Risks of Combining Shopping Experience and Artistic Elements in the Same Store: a Contribution to the Magical Functions of the Point of Sale. Journal of Marketing Management, 32(9-10), 944.

Xie, Y., \& Sun, J. (2018). How Does Embodiment Work in Dark Tourism "Field"? Based on Visitors' Experience in Memorial Hall of The Victims in Nanjing Massacre. International Journal of Tourism Cities, 4(1), 110-122.

Xu, J. B., \& Chan, A. (2010). A Conceptual Framework of Hotel Experience and Customer-Based Brand Equity: Some Research Questions and Implications. International Journal of Contemporary Hospitality, Vol. 22, No. 2, pp. 174-193.

Yoon, S.-J. (2013). Antecedents and Consequences of In-Store Experiences Based on an Experiential Typology. European Journal of Marketing, 47(5/6), 693-714. 


\section{APPENDIX}

\begin{tabular}{|c|}
\hline Indicators of Sense \\
\hline $\begin{array}{l}\text { X1: I feel Watsons has a musical background that is appropriate in volume } \\
\text { X2: I find Watsons a pleasant musical background } \\
\text { X3: I feel Watsons has the right temperature } \\
\text { X4: I find Watsons a pleasant indoor scent }\end{array}$ \\
\hline Indicators of Interior Design \\
\hline $\begin{array}{l}\text { X5: I find Watsons an interesting mix of design colors } \\
\text { X6: I feel Watsons has a modern decor style } \\
\text { X7: I feel Watsons has a suitable furniture design } \\
\text { X8: I feel Watsons has adequate room facilities }\end{array}$ \\
\hline Indicators of Signage \\
\hline $\begin{array}{l}\text { X9: The logo used on the shop helped me locate Watsons } \\
\text { X10: I find the division of areas in Watsons easy to understand } \\
\text { X11: The division of areas in Watsons makes it easy for me to find the product I want }\end{array}$ \\
\hline Indicators of Atmospherics \\
\hline $\begin{array}{l}\text { X12: I feel Watsons has a new, up-to-date product arrangement } \\
\text { X13: I feel Watsons has a very good product arrangement } \\
\text { X14: The layout in Watsons makes it easy for me to find the product I need } \\
\text { X15: I feel Watsons has the appropriate lighting } \\
\text { X16: I feel Watsons has a great atmosphere for shopping } \\
\text { X17: I feel Watsons has a clean room }\end{array}$ \\
\hline Indicators of Staff \\
\hline $\begin{array}{l}\text { X18: I feel that Watsons employees are willing to help me } \\
\text { X19: I feel Watsons has very friendly employees } \\
\text { X20: I feel that Watsons employees have a good knowledge of the product } \\
\text { X21: I feel that Watsons employees have a neat appearance } \\
\text { X22: I feel that Watsons employees have good or positive behavior } \\
\text { X23: I feel Watsons has very polite employees }\end{array}$ \\
\hline Indicators of Other Visitor's Behaviour \\
\hline $\begin{array}{l}\text { X24: I feel that other Watsons visitors have had the appearance to match } \\
\text { X25: I feel the other Watsons visitors have a good attitude } \\
\text { X26: I feel good at Watsons allowing me to interact with other people }\end{array}$ \\
\hline Indicators of The Visitor Himself/Herself \\
\hline $\begin{array}{l}\text { X27: I have a good knowledge of Watsons products } \\
\text { X28: I feel that Watsons employees can help me understand the product on offer } \\
\text { X29: I find it easy to get acquainted with the new products that Watsons has to offer when } \\
\text { shopping } \\
\text { X30: I find Watsons a very interesting place }\end{array}$ \\
\hline Indicators of Emotions \\
\hline $\begin{array}{l}\text { Y1: I have had a great time with my shopping experience at Watsons } \\
\text { Y2: I feel excited about the shopping experience at Watsons } \\
\text { Y3: I feel that I am more interested in the Watsons shopping experience }\end{array}$ \\
\hline Indicators of Satisfaction \\
\hline $\begin{array}{l}\text { Y4: I am very satisfied with the shopping experience at Watsons } \\
\text { Y5: I am satisfied with all the services that Watsons provides }\end{array}$ \\
\hline
\end{tabular}


Y6: Overall I am satisfied with Watsons

Indicators of Return Customer Loyalty

Y7: I am willing to recommend Watsons to my family / friends / relatives

Y8: I will give Watsons a positive recommendation

Y9: I'll be shopping again at Watsons

Y10: I am willing to buy more products at Watsons 